\title{
Towards authoritarianism. Internal situation in the Slovak Republic (1994-1998)
}

\begin{abstract}
This article discusses the internal situation of the Slovak Republic in the years 1994-1998, the period in which the country was governed by the coalition of Movement for Democratic Slovakia, the Slovak National Party and the Slovak Workers' Association, and the prime minister was Vladimír Mečiar. The main objective of the research was to analyse the actions undertaken by the coalition government in the context of violations of civil and political rights and freedoms, which could indicate an authoritarian way of exercising power and the dismantling of a democratic state of law. In the analysed period, the role of the parliamentary and nonparliamentary opposition was marginalised, the role of the media limited, the rights of national and ethnic minorities violated. There was also an ongoing, sharp conflict between Prime Minister Vladimír Mečiar and President Michál Kováč. The effect of this governance was the union of almost all political forces and seizure of power after the elections in 1998. In order to answer the research questions, the author used the method of institutional and legal analysis, decision analysis and the statistical method. The research confirmed the hypothesis that, against the background of other Visegrad Group countries, the Czech Republic, Poland and Hungary, in the case of Slovakia there were many instances of human rights violations in the period analysed. This led to the drastic deterioration of bilateral relations with many countries and the slowdown of Slovakia's accession to the North Atlantic Alliance and the European Union.
\end{abstract}

Key words: Vladimír Mečiar, Slovak Republik, human rights, Michál Kováč, Mikuláš Dzurinda

\section{Introduction}

O 1 January 1993, a new state emerged on the political map of Europe, as a result of the disintegration of the Czech and the Slovak Federal Republic: the Slovak Republic. The purpose of this article is to present the internal situation in Slovakia 1994-1998, namely the government of Vladimír Mečiar. The author tried to answer the question of to what extent the decisions taken by this government led to the dismantling of the democratic state of law and what consequences it had for the Slovak Republic in the international arena. The main hypothesis is that, compared to other countries of the Visegrad Group, in the case of Slovakia there were many instances of human rights violations and the result was a drastic deterioration of bilateral relations with the majority of states and slowdown in the process of accession to the North Atlantic Alliance (NATO) and the European Union (EU). The way power was exercised by the then coalition of the Movement for Democratic Slovakia (HZDS), the Slovakian National Party (SNS) and the Union of Slovak Workers (ZRS) was referred to by Timothy Garton-Ash as a democrature (Garton-Ash, 2000, pp. 408-414), whereas Viatscheslau Avioutskii quoted the words of the US Secretary of State Madelaine Albright, who described Slovakia as the "black hole of Europe" (Avioutskii, 2007, p. 21). In order to answer the research 
questions and to verify the hypothesis assumed in the study, the institutional and legal method was applied, which allowed me to analyse legal acts. Decisional analysis was of great importance, as it allowed me to present the situations and processes that were the culmination of decisions taken by representatives of the then authorities. Statistical methods were used to analyse data referring to the results of parliamentary elections.

\section{Parliamentary elections in 1994}

The elections of 30 September and 1 October 1994 shaped the political scene of Slovakia for almost four years, a scene which was clearly polarised into a government coalition and a completely marginalised opposition. The Movement for Democratic Slovakia won them once again, gaining similar support as two years earlier (35\%). The anti-Meciar coalition proved too weak to compromise the position of HZDS. First and foremost, it was the animosities between the politicians of the Christian Democratic Movement (KDH) and the Democratic Left Party (SDL) that determined the results (Parlamentné vol'by 1994...; Żarna, 2015, p. 108).

\section{Table 1}

Results of parliamentary elections in 1994

\begin{tabular}{|l|r|c|}
\hline \multicolumn{1}{|c|}{ Party } & $\begin{array}{c}\text { Result } \\
\text { (in \%) }\end{array}$ & $\begin{array}{c}\text { Number } \\
\text { of seats }\end{array}$ \\
\hline Movement for Democratic Slovakia & 35.0 & 61 \\
\hline Common Choice & 10.4 & 18 \\
\hline Hungarian Coalition & 10.2 & 17 \\
\hline Christian Democratic Movement & 10.1 & 17 \\
\hline Democratic Union of Slovakia & 8.6 & 15 \\
\hline Association of Slovak Workers & 7.3 & 13 \\
\hline Slovak National Party & 5.4 & 9 \\
\hline Democratic Party & 3.4 & - \\
\hline Communist Party of Slovakia & 2.7 & - \\
\hline Christian Social Union & 2.1 & - \\
\hline others & 4.8 & - \\
\hline Together & 100.0 & 150 \\
\hline
\end{tabular}

Source: Parlamentné vol'by 1994 on Slovensk, www.vysledkyvolieb.sk/parlamentne-volby/1994/vysledky, 29.07.2018.

The Movement for Democratic Slovakia this time stood for election in a coalition with the Slovak Agricultural Union (RSS), which was of little significance on the Slovak political scene. The second place was taken by the coalition Common Choice (SV) formed by SDL, Social Democratic Party of Slovakia (SDSS) and the Rural Workers' Movement (HPRS). The electoral results obtained by $\mathrm{KDH}$, the Hungarian Coalition created by the Hungarian Citizens' Party (MOS), the Hungarian Christian Democratic Movement (MKDH) and the Community (ESWS), as well as by the Democratic Union of Slovakia (DÚ) can be seen as confirmation of the stabilising position of these movements and political parties. The results of the elections confirmed the dominant position 
of HZDS. In turn, the lack of a stable political structure was the result of ongoing divisions on the political scene (Bajda, 2010a, pp. 78-83).

\section{The government of Vladimír Mečiar}

On 3-4 November 1994, an extraordinary parliamentary meeting was convened, during which the parliamentary majority centred around Vladimír Mečiar, while voting continuously for 23 hours, deprived the opposition of influence on the state. All parliamentary committees, television and radio supervisory boards, the Supreme Audit Office, the National Property Fund, the Prosecutor General's Office, and the Special Service Inspection Commissions were filled with government supporters. This event has gone down in history as the "night of long knives." In response, the European Union issued a démarche, expressing hope for the continuation of democratic reforms in Slovakia (Jagodziński, 1994, p. 6). The creation of a new coalition government consisting of HZDS, SNS and ZRS with Mečiar as Prime Minister on 13 December 1994, was not without a significant impact on the entirety of socio-political life. In the electoral manifesto of 1994, HZDS highlighted the need for further strengthening of state sovereignty and economic development. The program also included declarations on membership of the EU and NATO.

In the context of relations with neighbours, the readiness to sign agreements, among others, with Hungary, was declared. Cooperation within international organisations, including the UN, was to continue. In contacts with the Council of Europe, attention was paid to the need to respect the rights of persons belonging to national minorities and ethnic groups. The importance of systemic transformation in the economic sphere, too, was emphasised, as well as the activation of diplomatic means in order to achieve stabilisation in Central Europe (Košta, Greguš, 1996, p. 24).

In the case of the Slovak National Party, attention was paid to the priority of the national interests of the state, making membership of NATO and the EU dependent on the preservation of cultural diversity. The manifesto underlined the threats posed by the policy of persons belonging to the Hungarian minority in Slovakia and, as a result, the threat of the loss of part of its territory. The unstable situation in Ukraine, or the internationalisation of the crisis in the Balkans was also a major concern. In connection with the possibility of joining NATO, the SNS paid attention to the positive aspects of cooperation within the Partnership for Peace (PfP). The necessity of introducing the „Slovak Card" addressed to compatriots living mainly in the Czech Republic was presented (Košta, Greguš, 1996, p. 28).

The biggest surprise was the parliamentary entrance of the radical leftist Slovak Workers' Association (ZRS). The group was founded by a former politician of the Democratic Left Party (SDL') Ján Lupták. It was a demagogic party appealing to the electorate consisting of people dissatisfied with the consequences of socio-economic changes. The ZRS was reluctant towards the accession of Slovakia to NATO and the EU (Košta, Greguš, 1996, pp. 28-29). Ryszard Herbut noticed the fact that, analysing the left wing in Slovakia, one can distinguish two basic manifesto options: a democratic one, whose representative is SDL, and the so-called populist one, identified with the Communist Party 
of Slovakia (KSS) and the ZRS. Unlike both left-wing populist parties, SDL' supported market reforms, including privatisation, but it expected that this would not happen at the cost of lowering the standard of living of citizens. In the economic concept of this party, elements of the social market economy model with strong liberal elements were visible. This party opted for decentralisation of the decision-making process and strengthening the idea of local self-government. It strongly supported accession to Euro-Atlantic structures (Herbut, 1998, p. 144). Andrzej Antoszewski classified SDL' as the reformed postcommunist left, which accepted the principles of market economy and liberal democracy as a real alternative to the communist system (Antoszewski, 2005, p. 58).

Among the members of the new government there were twelve representatives of the HZDS, four of the ŽRS and two of the SNS. The new deputy Prime Ministers were Sergej Kozlík (Minister of Finance) and Katarina Tothova from HZDS, and union activist Jozef Kalman appointed by the ZRS. Juraj Schenk, a sociologist from Comenius University in Bratislava, took over the job of the Minister of Foreign Affairs. The creation of the coalition was made possible due to a change in the ZRS's position (Henderson, 2003, p. 92).

On 20 December 1995 the Prime Minister presented a statement of policy. Focusing on international policy, Mečiar emphasised that the continuity of actions which aimed at achieving full accession to the EU and NATO would be maintained. In regard to the first, it was assumed that Slovakia would become a member by 2000 at the latest, and for this purpose the government undertook to prepare a membership application. One of the government's priorities was to harmonise the legal system of the Slovak Republic with EU law. In the matter of international security, Mečiar stressed that the government would make efforts to join NATO, because membership would give Slovakia the greatest guarantee of security.

To this end, the government intended to intensify work under the PfP program and undertake actions to strengthen security in Europe, taking an active part in the work of the Council of Europe, the OSCE and the UN. The Prime Minister declared the intention to develop bilateral relations, first of all with the Czech Republic, Hungary and Poland, and to create favourable conditions for the development of political and economic cooperation. Among countries with whom cooperation was crucial, the Prime Minister counted the USA, Canada, Japan and Russia. He also announced the active participation of the government in the activities of international organisations dealing with the protection of human rights. All problems of representatives of national minorities and ethnic groups living on the territory of Slovakia were to be resolved in accordance with the provisions of the Constitution and of the applicable international agreements. Speaking on behalf of the government, Mečiar stressed that he condemned manifestations of intolerance, chauvinism, aggressive nationalism, racism, anti-Semitism and xenophobia. The implementation of the foreign policy objectives presented for the years 1994-1998, in the Prime Minister's opinion, would be successful mainly thanks to the professionalisation of the foreign and diplomatic service, consistently enforcing the interests of the state. The employees of the Ministry of Foreign Affairs were to positively distinguish themselves in terms of moral values and treat their work as a matter of honour and devotion to their homeland. An important task for the Slovak foreign service was to support the state's trade by creating conditions for the development of exports (Bajda, 2010b, 
p. 261). Mečiar also announced that he would seek to expel members of the Democratic Union from the parliament, because in his opinion they failed to collect the 10,000 signatures entitling them to participate in elections. Although the Main Electoral Commission and the Constitutional Court rejected these accusations, a special commission consisting of members of the HZDS, established during the extraordinary session of parliament, maintained these allegations and threatened sanctions. There was also anxiety in a large part of society. On 8 December 1994, Slovakian students organised a demonstration for the second time within a month with over 10,000 participants. In addition to the organisers, representatives of the Chancellery of President Michal Kováč, the Slovak Episcopate and the largest trade unions also appeared for the first time (Jagodziński, 1994, p. 6). During this period, the conflict between the head of state and the Prime Minister was escalating. When Kováč could not be forced to resign, HZDS and its coalition partners chose the tactics of limiting his competences. Having a majority in parliament, they gradually deprived the President of his powers, handing them over to the government. The battle between the two power centres reached its culmination on 5 May 1995. Just after the elections, parliament set up a commission to examine the circumstances of the dismissal of the first government of Mečiar and the role of the Slovak Information Service in the events of the time. The Commission presented the results of the investigation, which were supposed to indicate that the events of March 1994 had been inspired by the President himself. Despite many reservations, MPs from the government coalition voted in favour of a vote of no confidence in the President. This was inconsistent with the provisions of the Constitution, which is why the chairman of the parliament declared that the vote had no legal consequences for the President. It was aimed at creating a social atmosphere of condemnation of the head of state. Unable to deny the President the right to deliver a message, on 17 May, the public television authorities postponed his speech to late evening (Krajčir, 1995, p. 69). These events led to clear divisions in society. The opposition parties organised support rallies for the President. Paradoxically, at that time Michál Kováč, once a politician of the HZDS, became a symbol of struggle against Mečiar's authoritarian system of exercising power (Slobodnik, Chmel, 1995, pp. 8-9). On 6 September 1995, Kováč presented the State Report in parliament and referred to foreign policy. He noted that there were no circumstances prompting a change in its priorities. The process of accession to Euro-Atlantic structures remained one of the main factors determining the development of the state. The continuation of this direction was justified by historical and economic reasons, as well as the geopolitical location of Slovakia. In his opinion, strengthening the international position of the state depended on the arrangement of bilateral relations with neighbouring states, which was to be of importance for the whole of Central Europe. In this matter, the President demanded the further creation of a basis for the normalisation of Slovak-Hungarian relations (Pytlik, 2010 , p. 246). Mečiar's return to the post of Prime Minister was seen as an announcement of the escalation of conflicts in relations with the President. The main goal of the politicians of the new government coalition was to remove the President from office. The main obstacle to this task was the fact that the government coalition did not have the required qualified majority of $3 / 5$ of votes. In this situation, the politicians of the coalition parties took a number of actions leading to limiting the possibilities of action and discrediting Kováč. To achieve the intended purpose, Mečiar did not hesitate to use 
the special services. The actions undertaken became the reason for EU ambassadors to hand over to the government, on 25 October 1995, a démarche, which stressed that the government's actions against the President were inconsistent with the provisions of the Slovak Constitution and with the political practice of the EU countries that perceived these events with anxiety. A protest was also submitted by the US ambassador, who expressed concern about the further fate of Slovak democracy (Samson, 2001, p. 371). On 17 November 1995, the European Parliament (EP) passed a resolution on the need to respect human rights and the fate of democracy in Slovakia. The EP's concerns pertained not only to the actions of some political parties seeking to dismiss the head of state, or the participation of special service employees in actions to discredit the President, but also to disregarding representatives of the opposition when filling the positions of chairmen of the National Council of the Slovak Republic (National Council) or the so-called Act on the State Language of 1995 (Zákon NR SR č. 270/1995...). The EP also called for discussions on the issues presented in the forum of the European Parlament and National Council joint committees. The answer of the Slovak government to the resolution is interesting. In its opinion, it was a worthless monologue, harmful to Slovakia in the process of accession to the EU and NATO. In addition, government representatives stated that they regarded the resolution that had not been discussed with them to be unlawful (Bajda, 2010a, p. 94).

Human rights violations once again met an international reaction. In a statement issued on 7 March 1996, the International Organisation of Journalists protested against the abuse of economic resources to block the activities of independent press in Slovakia. During the general meeting at the end of October, the organisation addressed the situation in the Slovak media and expressed concern about the economic pressure exerted on independent means of communication (Madera, 2001, p. 180). In order to combat political opponents, in 1996 an attempt was made to amend the penal code. The new code prohibits activities of parties or organisations that would harm the state's defence or promote the spread of false information about the state. The President did not sign the amendment, fearing that the government would use the law to limit political party activities, and thus the new penal code was not implemented (Bajda, 2010a, pp. 94-95).

In addition to the scandal associated with the abduction of the President's son, a lot of emotions were stirred by the murder of Robert Remiás, which involved special services under the leadership of Ivan Lexa. This was one of the most influential figures in the analysed period. After graduating in chemistry at Polytechnic, he worked at the Slovnaft petrochemical company. In January 1991, he became the director of Prime Minister Vladimír Mečiar's office for several months. He was the first head of the chancellery of HZDS founded by Mečiar. After the party had won parliamentary elections in 1992, he was promoted to the government plenipotentiary for the organisation of the office of the President of Slovakia, and at the same time he was the head of the Office of the Council of Ministers. In the years 1993-1994, he was deputy Minister for Privatisation in the government of Mečiar, and then he headed the special services (SIS) until 1998. In 2000, he fled the country. In the summer of 2002, he was detained as an illegal immigrant in South Africa and deported to Slovakia (Lesná, 2008). Former SIS officer Oskar Fegyveres was the first to reveal that special forces had been responsible for the kidnapping of Kováč junior. On 29 April 1996, a car exploded with Remiáš on board. A later expert 
opinion ruled out the initial version that the accident was caused by a gas cylinder explosion; it was caused by a remotely controlled payload (Grabiński, 2002, p. 12).

During this period, the conflict between the President and the Prime Minister intensified further. On 22 May 1996, the aforementioned Ivan Lexa read a report in parliament in which, as enemies of the state, he named the President, opposition leaders and journalists. This speech made sense in the context of the SIS Information of 26 May 1995, the document found after the 1998 election, which was an analysis of the steps that secret services could take to bring about the resignation of the head of state. One scenario suggested investigating the activities of members of his family and finding materials that could compromise the relatives of Kováč. A second scenario was to build a constitutional majority to vote for the President's impeachment. A third scenario assumed abandoning attacks on the President, because he could become a symbol of democracy for the society around which they would unite (Bajda, 2010a, p. 94). First of all, Mečiar accused the Chancellery of the President that they were taking actions that made it an independent centre of foreign policy. In fact, these allegations were addressed to the organisational unit dealing with the generally understood foreign policy. The lack of their validity is evidenced by the fact that this unit of the Presidential Office, employing several people, dealt primarily with the organisation of foreign travel of the head of state, foreign correspondence and coordination of activities related to broadly understood foreign policy between the President and the government and parliament. It should be noted that every year the funds allocated for the activities of the Chancellery of the President were decreased in the budget act, which was one of the elements of conducting political struggle (Żarna, 1995, p. 116).

A lot of controversy arose from the case of Emil Spišák. He was to replace the late SNS MP Bartolomiej Kunc, but he did not take over this function as a result of internal fighting. He justified the deportations of the Jewish population during World War II, and he once became famous for claiming that national heritage had fallen into the hands of a small group of Jews (Avioutskii, 2007, p. 20). SNS nominated Ladislav Hruška. This was explained by the fact that, in the meantime, Spišak had left the party. He asked the Constitutional Court to investigate whether his rights had been violated. At the beginning of January 1998, the Court decided that National Council had violated Spišak's constitutional rights, preventing him from entering parliament. What is more, the parliament violated the International Covenant on Civil and Political Rights. According to the Court, National Council was obliged to abolish the adopted resolution on the entry of deputy Ladislav Hruška to the parliament and to give the seat to Emil Spišak. Contrary to the verdict, the majority coalition rejected this ruling (Madera, 2001, pp. 165-166).

An effect of the policy model pursued by Mečiar was the mobilisation of the opposition in face of the elections for the National Council proposed for 19 September 1998. In the autumn of 1996, the so-called Blue Coalition, composed of the centre-right parties, the Christian Democratic Movement, the Democratic Union of Slovakia and the Democratic Party was founded. On 3 July 1997, it was extended to include two left-wing parties, the Social Democratic Party of Slovakia and the Green Party in Slovakia, and this newly formed element of the Slovak political scene adopted the name of the Slovak Democratic Coalition (SDK). Politicians associated in its structures announced that, after victory in the election and the establishment of a government, they would make efforts in 
favour of Slovakia's return to the group of candidates for the EU and NATO. However, before the next parliamentary elections took place, the Prime Minister positively assessed the achievements of Slovak foreign policy in 1997 (Cichosz, 2010, p. 140).

Faced with the consolidation of the opposition, Mečiar attempted to change the electoral law. The bill was submitted in March 1998, only six months before the election date. This met with a fierce reaction from opposition politicians. The draft bill changed electoral constituencies by introducing one constituency. A lot of controversy arose from the amendment in which the Hagebach-Bishoff method of counting votes and the 5\% electoral threshold introduced in 1992 were maintained, but this solution applied to every political party, regardless of whether it was a part of a one-party election committee or an electoral coalition (Sokół, 2007, pp. 415-417).

An important aspect of the conflict between the head of state and the Prime Minister was the crisis associated with the next presidential election. The term of President Kováč's office expired on 2 March 1998 and the National Council, due to the inability to obtain the required majority of votes, was not able to elect a new president. From March 1998 to May 1999, according to the provisions of the Constitution, Mečiar was the head of state. The leader of HZDS used this situation to implement his own political plans. In this period, he dismissed 28 pro-opposition ambassadors and blocked proceedings pending in political matters, and four months before the next parliamentary elections introduced an amendment to the electoral law that would benefit his party. The aforementioned new ordinance imposed exceptionally high demands on the coalitions which concentrated most opponents of the government. In this situation, the opposition evolved from "party coalitions" into "coalition parties" with complex structures and names (Pytlik, 2010, p. 249). What Mečiar gained was that for several months the leaders of the opposition did not have time for the election campaign.

In addition to the mobilisation of opposition parties, representatives of non-governmental organisations played an important role. In October 1997, the Citizens' Campaign project came into being (OK-98). In March 1998, during the congress in Zvolen, 35 Slovak NGOs officially launched an initiative. The campaign focused on three basic goals: deepening the voters' awareness, ensuring a high turnout and increasing the influence of citizens on the election process by supervising it. As part of its activity, OK-98 initiated 60 educational projects that were addressed mainly at young people. According to Avioutskii, in 1998380,000 voters reached electoral age, which constituted $10 \%$ of those entitled to vote (Avioutskii, 2007, p. 24). The activity of OK-98 was met with a fierce attack from the pro-government "Slovenska Republika” which suggested that the organisation was financed by the USA. Two of the founders, Pavel Demeš and George Soros (,Slovenská Republika”...), were also attacked on its pages.

\section{Parliamentary election of 1998}

In the electoral manifesto of 1998, HZDS politicians paid special attention to economic relations, mainly regarding the need to attract foreign investment capital to Slovakia. The necessity of membership in NATO and the EU was also emphasised, but taking into account other arrangements and the geopolitical location of Slovakia. Nevertheless, 
the electoral manifesto was still different from the previous practice implemented by the government of Mečiar. In his comments, the head of the parliamentary committee for European integration, Augustin M. Húska, even argued that integration posed a threat of globalism, cosmopolitanism and the consumerist lifestyle of the West (Wlachovský, 1998, pp. 63-77).

Representatives of SNS strongly criticised the intention of Slovakia joining NATO and the EU. It was emphasised that Slovakia would lose much in EU structures, and NATO was blamed for conducting an aggressive military policy. The anti-NATO rhetoric was then particularly strong, due to the intervention in Kosovo. SNS leader Ján Slota, negatively oriented toward the Hungarian nation, stressed that its appearance in Europe was a real misfortune. There was strong criticism of the Slovak elite, who were accused of extreme cosmopolitanism. For the SNS, a pro-Russian policy was also hardly comprehensible, as Russia set itself visibly imperial political goals (Wlachovský, 1998, pp. 63-77). On 25-26 September 1998, elections to the National Council of the Slovak Republic were held and HZDS won again.

Table 2

Results of parliamentary elections in 1998

\begin{tabular}{|l|r|c|}
\hline \multicolumn{1}{|c|}{ Party } & $\begin{array}{c}\text { Result } \\
\text { (in \%) }\end{array}$ & $\begin{array}{c}\text { Number } \\
\text { of seats }\end{array}$ \\
\hline Movement for Democratic Slovakia & 27.0 & 43 \\
\hline Slovak Democratic Coalition & 26.3 & 42 \\
\hline Democratic Left Party & 14.7 & 23 \\
\hline The Hungarian Coalition Party & 9.1 & 15 \\
\hline Slovak National Party & 9.1 & 14 \\
\hline Party of the Civic Agreement & 8.0 & 13 \\
\hline Communist Party of Slovakia & 2.8 & - \\
\hline Association of Slovak Workers & 1.3 & - \\
\hline New Slovakia & 0.5 & - \\
\hline Slovak People's Party & 0.3 & - \\
\hline Hungarian People's Movement & 0.2 & - \\
\hline for Prosperity and Reconciliation & & - \\
\hline Independent Initiative & 0.2 & - \\
\hline Slovak National Unity & 0.1 & - \\
\hline Bečko - Revolutionary Workers' Party & 0.1 & - \\
\hline The Uniform Workers' Party of Slovakia & 0.1 & - \\
\hline Slovak National Alternative & 0.1 & - \\
\hline Movement of the Third Way & 0.1 & 150 \\
\hline Together & 100.0 & \\
\hline
\end{tabular}

Source: Parlamentné vol'by 1998 on Slovensko, www.vysledkyvolieb.sk/parlamentne-volby/1998/vysledky, 29.01.2018.

As already mentioned, the politicians put in a lot of work ahead of the election in order to unite their forces and ensure that no voter's voice of anti-Meciar views was wasted. An important role was played by the non-public television station Markiza, which obtained a broadcasting license during Mečiar's rule. He hoped that he would gain another advantage in the campaign, however it turned out otherwise. Markiza fiercely opposed 
the Prime Minister and constituted a significant force. To some extent, the director of Markiza television created the figure of Mikulaš Dzurinda as the future head of the government (Szimeczka, 1999, p. 18). In response, a report appeared on public television in which politicians associated with the KDH were attacked for allegedly having exported works of art abroad (Maćkowiak, 1998, p. 20).

Representatives of the OSCE missions present during the 1998 elections, invited by the Slovakian Foreign Ministry, decided that the elections had been carried out correctly. However, they were forced to note that, with the exception of Markiza, other TV stations were not objective in their comments, not hiding their pro-government sympathies. It was also pointed out that one could have reservations about the composition of electoral commissions which did not give opportunities to non-governmental organisations. Similar doubts were aroused by the electoral law itself, which could hinder Mečiar's opponents from creating a government coalition. The Prime Minister himself ran the campaign on a really impressive scale. On 10-13 September 1998, Claudia Cardinale and Gerard Depardieu, and the top model Claudia Schiffer (Green, 1998), took part in the HZDS pre-election meeting.

Despite electoral success, Mečiar did not manage to create a government that would have a parliamentary majority. In this situation, this mission was entrusted to the SDK leader Mikulaš Dzurinda. The negotiations lasted over a month, and the fact of entering the coalition by the representatives of the Hungarian minority aroused a lot of emotions. At the very beginning of talks on the creation of a coalition, SDL' politicians put forward the idea of forming a government without the participation of the Hungarians. Trying to discern the reasons for this objection, Rudolf Chmel claimed that the SDČ politicians probably were after ministerial seats, some of which would have been theirs if the Hungarians had not entered the government (Chmel, 1999, p. 21).

Finally, due to protests by the other coalition parties, the idea of SDL did not come into effect and representatives of the Hungarian minority entered the government. As Martin M. Šimečka remarks, many Slovaks realised that in the Slovak parliament, Hungarian deputies were the only ones who consistently voted for all acts of transformation and against all laws limiting democracy (Szimeczka, 1999, p. 18). The Hungarian Coalition Party (SMK) itself was also hastily created after Mečiar had changed the electoral law. It consisted of Béla Bugar's moderate Christian Democrats, Laslo Nagy's liberals and Miklos Duray's radical nationals. SMK in principle did not run an election campaign outside the regions inhabited by Hungarians. Nevertheless, young, educated Slovaks from large cities voted for this party (Maćkowiak, 1998, p. 20).

The coalition agreement was signed on 28 October. The government coalition was a peculiar phenomenon and did not have an equivalent in Europe. It was created by SDK, SDL, SMK and the Civic Alliance Party (SOP). SDK received nine ministries, SDL' six, and SMK three. Mikulaš Dzurinda became the head of the government that was a complicated conglomeration of various factions, and of which, paradoxically, the main binder was Mečiar himself, should the threat of his return turned out to be real (Szimeczka, 1999, p. 19). Mečiar did not hide his disappointment. On 30 September, in a TV speech, he rebuked voters who failed to support his party and would regret their decision in the near future, because the new coalition would sell Slovakia to the West. He finished his speech with tears. He gave up his parliamentary mandate to Ivan Lexa, 
and as a result, every request to hear the former head of the special services had to undergo a complicated parliamentary procedure to lift his immunity. Mečiar, acting as the head of state in the first half of 1998, granted an amnesty to his close associate and all those involved in the abduction of the son of the president. Although Dzurinda cancelled the decision on amnesty, the constitutional court decided that it still remained in force (Grabiński, 2002, p. 12).

According to Šimečka the September election proved to be a democratic revolution, the significance of which was greater than that of November 1989. At that time, the events had actually echoed those in Prague, and it had soon turned out that Slovak society had not yet been prepared for real change. Yet in 1998, the same society demonstrated great energy (Szimeczka, 1999, p. 21).

\section{Conclusion}

Among the countries of Central Europe, the internal situation of Slovakia had the greatest impact on the delay of the accession process to the North Atlantic Alliance and the European Union. While the Czech Republic, the Republic of Hungary and the Republic of Poland were invited to start accession negotiations during the EU summit in Luxembourg in 1997, the Slovak Republic was on the margins of this process. The Slovaks started negotiations under the provisions of the Helsinki summit in 1999, after Vladimír Mečiar had been removed from power. It was similar in the case of the North Atlantic Alliance; the three countries in question joined NATO in 1999, whereas Slovakia became a member a few years later. The key factor was the policy conducted in the years 1994-1998 by the coalition government of HZDS-SNS-ZRS under the leadership of Prime Minister Vladimír Mečiar. In this period there were many instances of violations of civil and political rights and freedoms. As a result of decisions taken by the then authorities, the opposition, both parliamentary and non-parliamentary, was completely marginalised. The rights of persons belonging to national and ethnic minorities, especially Hungarians and Roma, were also restricted. The opposition media also became the object of discrimination on the part of the rulers. The symbol of the political situation in this period was the conflict between Prime Minister Mečiar and the head of state. The government attempted to totally limit President Kováč's prerogatives and to discredit him in the eyes of the public. The Prime Minister even used the special services, which kidnapped the President's son. A number of actions taken in the years 1994-1998 explicitly pointed to an authoritarian way of exercising power. In none of the other countries of the Visegrad Group did such a situation occur, and the analogy could be traced rather in the Balkan states.

\section{Bibliography}

Antoszewski A. (2005), Partie polityczne w Europie Środkowej i Wschodniej, Wydawnictwo Forum Naukowe, Poznań.

Avioutskii V. (2007), Aksamitne rewolucje, Wydawnictwo Dialog, Warszawa.

Bajda P. (2010a), Elity polityczne na Stowacji w latach 1989-2010. Kręta droga do nowoczesnego państwa, Instytut Wydawniczy PAX, Warszawa. 
Bajda P. (2010b), Polityka zagraniczna Słowacji, in: Współczesna Słowacja. Sytuacja wewnętrzna i pozycja międzynarodowa, ed. E. Pałka, Oficyna Wydawnicza Arboretum, Wrocław.

Chmel R. (1999), Ruiny i mosty, "Gazeta Wyborcza” of 29 January.

Cichosz M. (2010), Gabinety na Stowacji po 1990 roku, in: Współczesna Słowacja. Sytuacja wewnętrzna i pozycja międzynarodowa, ed. E. Pałka, Wrocław.

Garton Ash T. (2000), Historia na goraco. Eseje i reportaże z Europy lat 90., Wydawnictwo Znak, Kraków.

Grabiński T. (2002), Kazat zabić?, "Gazeta Wyborcza” of 6 December.

Green P. S. (1998), Meciar Turns Out the Stars to Get Votes, "International Herald Tribune" 25 September, https://www.nytimes.com/1998/09/25/news/meciar-turns-out-the-stars-to-get-votes. html, 12.09.2018.

Henderson K. (2003), Slovakia. The escape from invisibility, Routledge, London-New York.

Herbut R. (1998), Systemy partyjne krajów Europy Centralnej i Wschodniej oraz wzorce rywalizacji politycznej, in: Demokracje Europy Środkowo-Wschodniej w perspektywie porównawczej, eds.

A. Antoszewski, R. Herbut, Wydawnictwo Uniwersytetu Wrocławskiego, Wrocław.

Jagodziński A. (1994), Mecziar trzeci raz, "Gazeta Wyborcza" of 13 December.

Košta J., Greguš P. (1996), Politické strany na Slovensku a ich program v rokoch 1990-1994, Inštitút Liberálnych Štúdií, Bratislava.

Krajčir L. (1995), Tatrzański wulkan, "Wprost" of 4 June.

Lesná L. (1998), Únos prezidetovho syna alebo krátke dejiny tajnej služby, GMT, Praha-Bratislava.

Maćkowiak T. (1998), ...Ponieśli i wilka?, "Gazeta Wyborcza” of 25 September.

Madera A. J. (2001), Na drodze do niepodległości. Słowacki system polityczny w okresie transformacji, SAS Wanda Tarnawska, Rzeszów.

Parlamentné vol'by 1994 na Slovensku, www.vysledkyvolieb.sk/parlamentnevolby/1994/vysledky, 29.01.2018.

Parlamentné vol'by 1998 na Slovensku, www.vysledkyvolieb.sk/parlamentnevolby/1998/vysledky, 29.01.2018.

Pytlik B. (2010), Polityka zagraniczna Republiki Stowackiej w latach 1993-1998, in: Administracja publiczna. Między polityka, prawem a ekonomiq. Jubileusz 10-lecia Katedry Akademii Publicznej Kolegium Ekonomiczno-Społecznego SGH, ed. J. Osiński, Warszawa.

Samson I. (2001), Slovakia: Misreading the Western Message, in: Democratic consolidation in Eastern Europe, vol. 2: International and Transnational Factors, eds. J. Zielonka, A. Pravda, Oxford University Press, Oxford.

Slobodnik D., Chmel R. (1995), Czemu Stowacy nie moga się zrozumieć, "Gazeta Wyborcza” of 11 August.

“Slovenská Republika” of 12 March, 21 July, 31 August, 9 and 21 September 1998.

Szimeczka M. M. (1999), Czyżby koniec paranoi?, "Gazeta Wyborcza” of 29 January.

Sokół W. (2007), Geneza i ewolucja systemów wyborczych w państwach Europy Środkowej $i$ Wschodniej, Wydawnictwo Uniwersytetu Marii Curie-Skłodowskiej, Lublin.

The International Covenant on Civil and Political Rights, United Nations General Assembly Resolutions 2200A (XXI), 19 XII 1966.

Wlachovský M. (1998), Zahraničná politika, in: Vol’by 1998. Analýza volebných programov politických strán a hnutí, ed. G. Mesežnikov, Inštitút pre verejné otázky, Bratislava.

Zákon NR SR č. 270/1995 Z. z. o štátnom jazyku Slovenskej republiky.

Żarna K. (2015), Od Mečiara do Dzurindy. Główne kierunki polityki zagranicznej Republiki Słowackiej w latach 1993-2002, Wydawnictwo Uniwersytetu Rzeszowskiego, Rzeszów. 


\section{W stronę autorytaryzmu. Sytuacja wewnętrzna w Republice Słowackiej (1994-1998)}

\section{Summary}

Niniejszy artykuł dotyczy sytuacji wewnętrznej Republiki Słowackiej w latach 1994-1998, czyli okresu, w którym rządy w tym państwie sprawowała koalicja Ruchu na rzecz Demokratycznej Słowacji, Słowacka Partia Narodowa i Zrzeszenie Robotników Słowackich, a funkcję premiera pełnił Vladimír Mečiar. Głównym celem badań była analiza działań podejmowanych przez koalicyjny rząd w kontekście naruszeń praw i wolności obywatelskich i politycznych, co mogło wskazywać na autorytarny sposób sprawowania władzy i demontaż demokratycznego państwa prawa. W analizowanym okresie doszło do zmarginalizowania roli opozycji parlamentarnej i pozaparlamentarnej, ograniczenia roli mediów, naruszenia praw mniejszości narodowych i etnicznych, a także ostrego sporu pomiędzy premierem Vladimírem Mečiarem a prezydentem Michálem Kováčem. Efektem tych rządów było zjednoczenie niemal wszystkich sił politycznych i przejęcie władzy po wyborach w $1998 \mathrm{r}$. W celu odpowiedzi na pytania badawcze autor posłużył się metodą analizy instytucjonalno-prawnej, analizy decyzyjnej i metody statystycznej. W wyniku badań potwierdzono założoną hipotezę, że głównym założeniem artykułu jest stwierdzenie, że na tle innych państw Grupy Wyszehradzkiej: Czech, Polski i Węgier w przypadku Słowacji dochodziło do wielu przypadków naruszeń praw człowieka. Implikacją tego było drastyczne pogorszenie bilateralnych stosunków z wieloma państwami i spowolnienie procesu akcesji Słowacji do Sojuszu Północnoatlantyckiego i Unii Europejskiej.

Słowa kluczowe: Vladimír Mečiar, Republika Słowacka, prawa człowieka, Michál Kováč, Mikuláš Dzurinda 
